\title{
Validation of the Charge Equalization Principles during the Formation of Small Molecules
}

\section{Yük Dengelenme Prensiplerinin Küçük Moleküllerin Oluşumundaki Geçerliliği}

\section{Research Article}

\section{Savaş Kaya'",Cemal Kaya', Nazmul Islam², Ime Bassey Obot ${ }^{3}$}

'Department of Chemistry, Cumhuriyet University, Sivas, Turkey.

${ }^{2}$ Theoretical and Computational Chemistry Research Laboratory, Department of Basic Science \& Humanities/Chemistry, Techno Global-Balurghat, Balurghat, D. Dinajpur, India.

${ }^{3}$ Centre of Research Excellence in Corrosion, Research Institute, King Fahd University of Petroleum and Minerals, Dhahran, Kingdom of Saudi Arabia.

\section{A B S TR ACT}

T

he electrophilicity equalization principle recently presented by Chattaraj and his co-workers has been criticized by Szentpaly. In the present report, we found that the charge equalization process for small molecule is successfully depicted by the geometrical mean models but for very big molecules the existing geometrical mean models failed to depict the charge equalization scenario. The expressed good agreement between the results obtained from our equation and the results obtained from geometric mean equation vide supra, leads us to conclude that Chattaraj's geometric mean equation and other equalization principles are still useful and cannot be ignored completely.

\section{Key Words}

Hardness, elektronegativity, electrophilicity, Charge Equalization Principles.

\section{Ö z}

\begin{abstract}
hattaraj ve çalışma arkadaşları tarafından ortaya konulan Elektrofilikliğin Dengelenmesi IIlkesi Szentpaly tarafından değerlendirilmiştir. Bu çalışmada yük dengelenme süreçlerinin ve geometrik ortalama denklemlerinin küçük moleküllerin oluşumu için geçerli olduğu, fakat büyük moleküllerde başarılı olmadığı gösterilmiştir. Kaya, moleküler sertlik ve moleküler elektronegatiflik denklemleri kullanılarak elde edilen elektrofiliklik değerleri ve geometrik ortalama denklemleri kullanılarak elde edilen elektrofiliklik değerleri arasındaki kayda değer uyum, Chattaraj'ın sunduğu Elektrofilikliğin dengelenmesi ilkesinin gözardı edilemeyecek bir ilke olduğunu ve küçük moleküllerin oluşumunda geçerli olduğunu göstermiştir.
\end{abstract}

\section{Anahtar Kelimeler}

Sertlik, elektronegatiflik, elektrofiliklik, Yük dengelenme ilkeleri.

Article History: Received: May 25, 2016; Revised: Jun 18, 2016; Accepted: Sep 15, 2016; Available Online: Apr 1, 2017 


\section{INTRODUCTION}

Conceptual Density Functional Theory (CDFT) [1-3] provides great conveniences to chemists for understanding of chemical reactivity. Chemical reactivity descriptors such as chemical hardness $(\eta)[4,7]$, chemical potential $(\mu)[8]$ and electronegativity $(\chi)[9,10]$ can be calculated considering ionization energy (I) and electron affinity (A) values of chemical species through the contributions to quantum chemistry of this theory.

In the literature, popular electronic structure principles regarding electronegativity, chemical hardness and electrophilicity concepts are available. The first of them is Sanderson's electronegativity equalization principle [11,12]. The electronegativity equalization principle states that when two or more different atoms combine to form a molecule, their electronegativities change to a common intermediate value and become equalized. Together with the electronegativity equalization principle, Sanderson proposed the geometric mean principle for the calculation of molecular electronegativity from atomic electronegativities. According to the geometric mean principle, molecular electronegativity $(\chi \mathrm{M})$ can be approximately calculated via the following equation from the electronegativities of isolated atoms in the molecule.

$$
\chi_{M}=\left(\prod_{i=1}^{N} \chi_{i}\right)^{1 / N}
$$

where, $\mathrm{N}$ is the number of atoms in the molecule, $\chi \mathrm{i}(\mathrm{i}=1,2, \ldots . \mathrm{N})$ is the electronegativity of isolated atoms.

Chemical hardness is an extremely meaningful concept in terms of understanding of chemical reactivity and stability of chemical systems [13-15]. Chemical principles based on chemical hardness concept such as Hard and Soft Acid-Base Principle (HSAB) [16-19] and Principle of Maximum Hardness (PMH) [20-22] present theoretical justification to chemists for many issue of chemistry. In 1996, Dipankar Datta [23] proposed that chemical hardness is also equalized during molecule formation like electronegativity and geometric mean equation can be used for the evaluation of the molecular hardness $(\eta \mathrm{M})$ from chemical hardness values of constituent atoms. It should be stated that the first hints about global hardness equalization principle was proposed by Datta. Molecular hardness equation presented by Datta is given below.

$$
\eta_{M}=\left(\prod_{i=1}^{N} \eta_{i}\right)^{1 / N}
$$

In 2010, Pratim Kumar Chattaraj and his students proposed the electrophilicity equalization principle [24] considering global hardness equalization principle and Sanderson's electronegativity equalization principle. According to Parr's electrophilicity index [25] $\left(\omega=\chi_{2} / 2 \eta\right)$, electrophilicity of a chemical species is based on its chemical hardness and electronegativity values. For this reason, it is also necessary to discuss on the concept of chemical hardness equalization principle and electronegativity equalization principle in addition to electrophilicity equalization principle. If global hardness equalization principle and electronegativity equalization principle are valid, one can say that electrophilicity equalization principle would be valid automatically. Chattaraj's geometric mean equation for molecular electrophilicity $(\omega \mathrm{M})$ is given below.

$$
\omega_{M}=\left(\prod_{i=1}^{N} \omega_{i}\right)^{1 / N}
$$

Chemical equalization principles mentioned above have many applications in chemistry. If electronic structure principles such as chemical hardness equalization principle, electronegativity equalization principle and electrophilicity equalization principle are examined with unbiased perspective, both important applications and setbacks are noticeable. For example, geometric mean equations regarding reactivity descriptors provide the possibility for the estimation of reactivity or stability of chemical species. On the other hand, it is important to note that chemical equalization principles have been demonstrated considering only small molecules. Sanderson has suggested the electronegativity equalization principle taking into account mostly diatomic and triatomic molecules. In analogy, Dipankar Datta has advocated the global hardness equalization principle and geometric mean equation for molecular hardness for simple molecules in his 
publications. The same thing can be also said for electrophilicity equalization principle of Chattaraj whereby, chemical equalization principles are very useful. So why is only simple and small molecules attracting attention in publications about chemical equalization principles. After Chattaraj's electrophilicity equalization principle, Szentpaly has severely criticized this electronic structure principle considering large metal clusters and fullerenes [26-28]. In his paper, Szentpaly indicated that electrophilicity equalization principle is not useful and reasonable for molecule formation and showed that electrophilicity increases with cluster size. This statement is sufficient to understand the effect on equalizations of chemical reactivity indexes such as chemical hardness, electronegativity and electrophilicity of molecular size [29]. It is apparent that equalization assumptions for electrophilicity, electronegativity and chemical hardness in large molecules is not reasonable. In addition to Szentpaly's criticism, Datta [30] who proposed the geometric mean equation for molecular hardness has made an important work regarding electrophilicity equalization with Szentpaly and Shee. As a result of this study, they noted that in general, basic assumption of electronegativity equalization principle cannot be corroborated by experimental data, the applicability and accuracy of electronegativity equalization principle should not be exaggerated and it can lead to misconceptions to consider as negative of chemical potential the electronegativity. This relation given by $\chi=-\mu$ has been criticized by Pearson [31] and Allen [32]. Both Pearson and Allen have proposed that Pauling's electronegativity and the chemical potential should be regarded as two separate and distinct properties. Later on, similar criticisms related to this topic were made by Politzer and his co-workers [33-35] about the validity of $\chi=-\mu$. Furthermore, we want to state that studies which support the equalization principles and the ones which criticize it can all be found in the literature. The aim of the present paper is to support the electrophilicity equalization principle and also to provide useful information regarding the application of geometric mean equations, molecular electronegativity, molecular hardness and molecular electrophilicity.
New Equations for the Calculation of Molecular Electronegativity, Molecular Hardness and Molecular Electrophilicity

Electronegativity equalization principle is defined in terms of charge-dependent property by Sanderson. According to this principle, in a molecule formed by atoms whose electronegativities are different, electronegativities of the atoms are equilibrated as a result of electron transfer between atoms. In recent years, we derived a new equation to calculate the electronegativities of molecules from ionization energy and electron affinity values of constitute atoms using Sanderson's electronegativity equalization principle and Iczkowski-Margrave electronegativity definition [36]. The mentioned new molecular electronegativity equation is given as [37]:

$$
\chi_{M}=\frac{\sum_{i=1}^{N}\left(\frac{I_{i}+A_{i}}{I_{i}-A_{i}}\right)+2 q_{M}}{\sum_{i=1}^{N}\left(\frac{2}{I_{i}-A_{i}}\right)}
$$

where, $\chi_{M}$ and $q_{M}$ are electronegativity and charge of molecule or functional group, respectively. $\mathrm{N}$ is number of atoms in the molecule and $\mathrm{Ii}$ and $\mathrm{Ai}$ are the ionization energy and electron affinity of i-th atom.

We have also derived another equation to calculate the molecular hardness using the global hardness equalization principle as [38]:

$$
\eta_{M}=\frac{\left(2 \sum_{i=1}^{N} \frac{b_{i}}{a_{i}}\right)+q_{M}}{\sum_{i=1}^{N} \frac{1}{a_{i}}}
$$

In this equation, $\eta \mathrm{M}$ and $\mathrm{qM}$ are chemical hardness of molecule and charge of molecule, respectively. $\mathrm{N}$ is number of atoms in molecule. ai and bi parameters related ionization energy and electron affinity for any atom in molecule are given as follows and these are defined as $a_{i}=(I+A) / 2$ and $b i=(I-A) / 2$.

Molecular electronegativity and molecular hardness equations derived by us have some advantages compared to corresponding geometric mean equations proposed by Sanderson and Datta. Using the new equations, molecular 
electronegativity and molecular hardness values for both neutral molecules and charged molecules can be calculated. On the other hand, geometric mean equations for chemical reactivity indices can only be calculated for neutral molecules. It is also possible to calculate the electrophilicity values of charged molecules because electrophilicity of a molecule is associated with its chemical hardness and electronegativity according to Parr's electrophilicity index. Consequently, one can write the following equation considering Parr's electrophilicity index using Equation 4 and Equation 5.

$$
\omega_{M}=\frac{\chi_{M}{ }^{2}}{2 \eta_{M}}=\frac{\left[\sum_{i=1}^{N}\left(\frac{I_{i}+A_{i}}{I_{i}-A_{i}}\right)+2 q_{M} / \sum_{i=1}^{N}\left(\frac{2}{I_{i}-A_{i}}\right)\right]^{2}}{2\left[\left(2 \sum_{i=1}^{N} \frac{I_{i}-A_{i}}{I_{i}+A_{i}}\right)+q_{M} / \sum_{i=1}^{N} \frac{1}{I_{i}-A_{i}}\right]}
$$

To support the chemical equalization principles, especially Chattaraj's electrophilicity equalization principle, firstly, we compared the results of geometric mean equations with the results of our new equations. Then, we showed that these electronic structure principles are useful to use in small molecules.

\section{RESULTS and DISCUSSION}

In Table 1, Table 2 and Table 3, the results of geometric mean equations and the results of our method of calculations of electronegativities, chemical hardnesses and electrophilicities of some selected molecules have been compared. For the comparisons, especially small molecules have been considered. In previous works we have pointed out that the proposed equations (Eq.5 and Eq.6) are very useful to calculate the electronegativities and chemical hardnesses of simple molecules and it is seen from the graphs that there is a nice correlation between the two sets of results- results of our equations and the results geometric mean equations. Especially, the results of Chattaraj's method for molecular electrophilicity are very close to our electrophilicity values. Figure 3 support this idea. We propose that chemical equalization principles is valid for simple molecules and geometric mean equations with respect to computing electrophilicity, electronegativity and chemical hardness should be applied for simple molecules, otherwise, wrong results can be obtained. Moreover, it will be out of place to ignore completely the Chattaraj's electrophilicity equalization principle.

Islam and Ghosh $[39,40]$ have critically analyzed the comment of Szentpaly that there is no support of "hardness equalization principle" and "electrophilicity equalization principle" and pointed out that Szentpaly erred in conceiving proper domain of the equalization phenomenon. The process of charge equalization occurs only during the chemical event of hetero nuclear molecule formation. This charge equalization phenomenon cannot be used in case of the formation of homo nuclear molecules because there is no whisper of charge transfer.

After analyzing the agreement between the results obtained from our equation with the results obtained from geometric mean equation as presented above, we make the following comments with respect to the experimental data. As is known, chemical hardness, chemical potential and electronegativity are defined via the following equations based on ionization energy (I) and electron affinity (A) values of chemical species [41-45]. According to Parr's electrophilicity index, electrophilicity of any chemical species is associated with its chemical hardness and electronegativity.

$$
\begin{gathered}
\chi=-\mu=\frac{I+A}{2} \\
\eta=I-A
\end{gathered}
$$

In Table 4, we have presented three sets of chemical hardness, electronegativity and electrophilicity data of some chosen molecules using three different methods. The first sets of data are computed using Parr and Pearson's operational and approximate method of calculation of electronegativity $[\chi=1 / 2(I+A)]$, hardness $[\eta=(I-A)]$, and Parr et al definition of electrophilicity $\left[\omega=\chi_{2} / 2 \eta\right]$. In order to compute the above mentioned parameters of the molecules 
Table 1. Calculated Chemical Hardness Values for Some Selected Molecules (eV).

\begin{tabular}{|c|c|c|}
\hline \multirow{2}{*}{ Molecule } & \multicolumn{2}{|c|}{ Chemical Hardness Value } \\
\hline & Kaya & Datta's Geometric Mean Equation \\
\hline $\mathrm{C}_{5} \mathrm{H}_{5} \mathrm{~N}$ & 11.59 & 11.59 \\
\hline $\mathrm{C}_{6} \mathrm{H}_{5} \mathrm{SH}$ & 11.08 & 11.07 \\
\hline $\mathrm{HCONH}_{2}$ & 12.45 & 12.45 \\
\hline $\mathrm{CH}_{4}$ & 12.22 & 12.22 \\
\hline $\mathrm{CH}_{3} \mathrm{COCH}_{3}$ & 11.86 & 11.86 \\
\hline $\mathrm{BeO}$ & 10.24 & 10.47 \\
\hline $\mathrm{MgO}$ & 8.88 & 9.29 \\
\hline $\mathrm{CaO}$ & 7.84 & 8.60 \\
\hline Bes & 8.70 & 8.63 \\
\hline MgS & 7.57 & 7.67 \\
\hline CaS & 6.81 & 7.10 \\
\hline $\mathrm{Brl}$ & 7.89 & 7.89 \\
\hline so & 9.84 & 10.03 \\
\hline $\mathrm{OH}$ & 12.50 & 12.50 \\
\hline $\mathrm{NH}$ & 13.64 & 13.64 \\
\hline $\mathrm{F}_{2}$ & 14.02 & 14.02 \\
\hline $\mathrm{S}_{2}$ & 8.28 & 8.28 \\
\hline $\mathrm{CS}_{2}$ & 8.84 & 8.82 \\
\hline $\cos$ & 10.94 & 10.02 \\
\hline $\mathrm{SO}_{2}$ & 10.69 & 10.69 \\
\hline $\mathrm{SO}_{3}$ & 11.04 & 11.04 \\
\hline $\mathrm{O}_{3}$ & 12.16 & 12.16 \\
\hline $\mathrm{N}_{2} \mathrm{O}$ & 13.70 & 13.65 \\
\hline $\mathrm{PBr}_{3}$ & 8.84 & 8.75 \\
\hline $\mathrm{PCl}_{3}$ & 9.48 & 9.46 \\
\hline $\mathrm{POCl}_{3}$ & 10.00 & 9.95 \\
\hline $\mathrm{CH}_{3} \mathrm{I}$ & 11.10 & 10.94 \\
\hline $\mathrm{HNO}_{3}$ & 12.76 & 12.73 \\
\hline $\mathrm{SF}_{6}$ & 12.76 & 13.00 \\
\hline $\mathrm{CF}_{3} \mathrm{Br}$ & 11.64 & 11.83 \\
\hline $\mathrm{H}_{2} \mathrm{O}$ & 12.62 & 12.62 \\
\hline $\mathrm{H}_{2} \mathrm{~S}$ & 11.18 & 11.10 \\
\hline $\mathrm{NH}_{3}$ & 13.24 & 13.24 \\
\hline $\mathrm{CO}_{2}$ & 11.34 & 11.39 \\
\hline $\mathrm{CH}_{3} \mathrm{CN}$ & 12.06 & 12.06 \\
\hline
\end{tabular}


60 | S. Kaya et al. / Hacettepe J. Biol. \& Chem., 2017, 45 (1), 55-66

Table 1. Calculated Chemical Hardness Values for Some Selected Molecules (eV). (continue)

\begin{tabular}{ccc}
\hline $\mathrm{C}_{2} \mathrm{H}_{2}$ & 11.34 & 11.34 \\
\hline $\mathrm{CH}_{3} \mathrm{Cl}$ & 11.60 & 11.48 \\
\hline $\mathrm{BCl}_{3}$ & 8.84 & 9.00 \\
\hline $\mathrm{HCN}$ & 12.30 & 12.30 \\
\hline$\left(\mathrm{CH}_{3}\right) 3 \mathrm{P}$ & 11.86 & 11.88 \\
\hline $\mathrm{C}\left(\mathrm{CH}_{3}\right) 4$ & 11.94 & 11.94 \\
\hline$\left(\mathrm{CH}_{3}\right) 2 \mathrm{~S}$ & 11.60 & 11.58 \\
\hline
\end{tabular}

Table 2. Comparison of the electronegativities calculated by Sanderson and Kaya equation.

\begin{tabular}{|c|c|c|c|c|c|}
\hline \multirow{2}{*}{$\begin{array}{l}\text { Group/ } \\
\text { Molecule }\end{array}$} & \multicolumn{2}{|c|}{ Molecular Electronegativity } & \multirow{2}{*}{$\begin{array}{l}\text { Group/ } \\
\text { Molecule }\end{array}$} & \multicolumn{2}{|c|}{ Molecular Electronegativity } \\
\hline & Kaya & Sanderson & & Kaya & Sanderson \\
\hline $\mathrm{CH}_{3}$ & 6.90 & 6.94 & $\mathrm{C}_{5} \mathrm{H}_{5} \mathrm{~N}$ & 6.71 & 6.76 \\
\hline $\mathrm{CH}_{3} \mathrm{CH}_{2}$ & 6.87 & 6.90 & $\mathrm{C}_{6} \mathrm{H}_{5} \mathrm{SH}$ & 6.62 & 6.67 \\
\hline$\left(\mathrm{CH}_{3}\right)_{2} \mathrm{CH}$ & 6.85 & 6.89 & $\mathrm{HCONH}_{2}$ & 7.07 & 7.09 \\
\hline$\left(\mathrm{CH}_{3}\right)_{3} \mathrm{C}$ & 6.84 & 6.88 & $\mathrm{CH}_{4}$ & 6.96 & 6.99 \\
\hline $\mathrm{C}_{6} \mathrm{H}_{6}$ & 6.67 & 6.71 & $\mathrm{CH}_{3} \mathrm{COCH}_{3}$ & 6.90 & 6.92 \\
\hline $\mathrm{C}_{6} \mathrm{H}_{5} \mathrm{NH}_{2}$ & 6.74 & 6.78 & $\mathrm{NaF}$ & 4.72 & 5.44 \\
\hline $\mathrm{C}_{6} \mathrm{H}_{5} \mathrm{OH}$ & 6.73 & 6.77 & $\mathrm{NaCl}$ & 4.64 & 4.86 \\
\hline$\left(\mathrm{CH}_{3}\right)_{3} \mathrm{~N}$ & 6.93 & 6.96 & $\mathrm{BeO}$ & 6.02 & 6.08 \\
\hline $\mathrm{CH}_{2} \mathrm{O}$ & 6.99 & 7.03 & $\mathrm{MgO}$ & 5.24 & 5.32 \\
\hline $\mathrm{CH}_{3} \mathrm{CHO}$ & 6.92 & 6.95 & Bes & 5.59 & 5.52 \\
\hline $\mathrm{CH}_{3} \mathrm{COOH}$ & 7.00 & 7.00 & MgS & 4.95 & 4.83 \\
\hline $\mathrm{CH}_{3} \mathrm{NO}_{2}$ & 7.14 & 7.16 & $\mathrm{Brl}$ & 7.15 & 7.16 \\
\hline $\mathrm{CH}_{2} \mathrm{~F}$ & 7.63 & 7.62 & so & 6.75 & 6.85 \\
\hline $\mathrm{CHF}_{2}$ & 8.34 & 8.35 & $\mathrm{OH}$ & 7.37 & 7.36 \\
\hline $\mathrm{CHFCl}$ & 7.91 & 7.90 & $\mathrm{NH}$ & 7.24 & 7.24 \\
\hline $\mathrm{CHClBr}$ & 7.37 & 7.30 & $\mathrm{~F}_{2}$ & 10.41 & 10.41 \\
\hline $\mathrm{CClBrl}$ & 7.22 & 7.19 & $\mathrm{~S}_{2}$ & 6.22 & 6.22 \\
\hline $\mathrm{SiH}_{3}$ & 6.24 & 6.48 & $\mathrm{CS}_{2}$ & 6.23 & 6.23 \\
\hline $\mathrm{SiF}_{3}$ & 8.10 & 8.56 & $\cos$ & 6.59 & 6.65 \\
\hline $\mathrm{NF}_{2}$ & 9.39 & 9.25 & $\mathrm{SO}_{2}$ & 6.98 & 7.07 \\
\hline $\mathrm{NCl}_{2}$ & 8.06 & 7.95 & $\mathrm{SO}_{3}$ & 7.11 & 7.18 \\
\hline $\mathrm{NH}_{2}$ & 7.22 & 7.22 & $\mathrm{O}_{3}$ & 7.54 & 7.54 \\
\hline $\mathrm{N}\left(\mathrm{CH}_{3}\right)_{2}$ & 6.94 & 6.98 & $\mathrm{~N}_{2} \mathrm{O}$ & 7.41 & 7.38 \\
\hline $\mathrm{NHOH}$ & 7.19 & 7.30 & $\mathrm{PBr}_{3}$ & 7.15 & 7.04 \\
\hline $\mathrm{PH}_{2}$ & 6.56 & 6.62 & $\mathrm{PCl}_{3}$ & 7.67 & 7.52 \\
\hline $\mathrm{PCl}_{2}$ & 7.47 & 7.29 & $\mathrm{POCl}_{3}$ & 7.63 & 7.53 \\
\hline
\end{tabular}


Table 2. Comparison of the electronegativities calculated by Sanderson and Kaya equation. (continue)

\begin{tabular}{|c|c|c|c|c|c|}
\hline $\mathrm{PF}_{2}$ & 8.40 & 8.47 & $\mathrm{CH}_{3} \mathrm{I}$ & 6.87 & 6.90 \\
\hline OF & 8.88 & 8.86 & $\mathrm{HNO}_{3}$ & 7.43 & 7.42 \\
\hline $\mathrm{OCl}$ & 7.97 & 7.91 & $\mathrm{SF}_{6}$ & 9.49 & 9.67 \\
\hline $\mathrm{BrCl}$ & 7.93 & 7.94 & $\mathrm{CF}_{3} \mathrm{Br}$ & 8.68 & 8.83 \\
\hline $\mathrm{NF}_{3}$ & 9.65 & 9.53 & $\mathrm{H}_{2} \mathrm{O}$ & 7.30 & 7.30 \\
\hline $\mathrm{NCl}_{3}$ & 8.12 & 8.04 & $\mathrm{H}_{2} \mathrm{~S}$ & 6.76 & 6.84 \\
\hline IF & 8.02 & 8.38 & $\mathrm{NH}_{3}$ & 7.20 & 7.20 \\
\hline $\mathrm{HF}$ & 8.70 & 8.65 & $\mathrm{CO}_{2}$ & 7.06 & 7.09 \\
\hline $\mathrm{HCl}$ & 7.83 & 7.72 & $\mathrm{CH}_{3} \mathrm{CN}$ & 6.85 & 6.88 \\
\hline $\mathrm{HBr}$ & 7.42 & 7.38 & $\mathrm{C}_{2} \mathrm{H}_{2}$ & 6.67 & 6.71 \\
\hline $\mathrm{BF}_{2}$ & 7.56 & 7.74 & $\mathrm{CH}_{3} \mathrm{Cl}$ & 7.25 & 7.19 \\
\hline $\mathrm{BCl}_{2}$ & 6.82 & 6.66 & $\mathrm{BCl}_{3}$ & 7.18 & 7.04 \\
\hline $\mathrm{Be}\left(\mathrm{CH}_{3}\right)_{2}$ & 6.62 & 6.68 & $\mathrm{HCN}$ & 6.84 & 6.90 \\
\hline $\mathrm{BF}_{3}$ & 8.16 & 8.34 & $\left(\mathrm{CH}_{3}\right) 3 \mathrm{P}$ & 6.79 & 6.83 \\
\hline $\mathrm{PH}_{3}$ & 6.70 & 6.75 & $\mathrm{C}\left(\mathrm{CH}_{3}\right) 4$ & 6.86 & 6.90 \\
\hline$\left(\mathrm{CH}_{3}\right)_{2} \mathrm{O}$ & 6.98 & 7.00 & $\left(\mathrm{CH}_{3}\right) 2 \mathrm{~S}$ & 6.80 & 6.86 \\
\hline $\mathrm{SCN}$ & 6.50 & 6.58 & NO & 7.43 & 7.42 \\
\hline $\mathrm{COOH}$ & 7.09 & 7.11 & $\mathrm{CO}$ & 6.84 & 6.88 \\
\hline
\end{tabular}

Table 3. Calculated Electrophilicity Values for Some Selected Molecules (eV).

\begin{tabular}{ccc}
\hline & & Electrophilicity value \\
Molecule & Kaya & $\begin{array}{c}\text { Chattaraj's Geometric Mean } \\
\text { Equation }\end{array}$ \\
\cline { 2 - 3 } $\mathrm{C}_{5} \mathrm{H}_{5} \mathrm{~N}$ & 1.942 & 1.966 \\
\hline $\mathrm{C}_{6} \mathrm{H}_{5} \mathrm{SH}$ & 1.977 & 2.004 \\
\hline $\mathrm{HCONH}_{2}$ & 2.007 & 2.016 \\
\hline $\mathrm{CH}_{4}$ & 1.982 & 1.992 \\
\hline $\mathrm{CH}_{3} \mathrm{COCH}_{3}$ & 2.007 & 2.018 \\
\hline $\mathrm{BeO}$ & 1.769 & 1.727 \\
\hline $\mathrm{CH}_{2} \mathrm{O}$ & 2.055 & 2.067 \\
\hline $\mathrm{BeS}$ & 1.795 & 1.726 \\
\hline $\mathrm{MgS}$ & 1.618 & 1.651 \\
\hline $\mathrm{Br}$ & 3.239 & 3.236 \\
\hline $\mathrm{SO}$ & 2.315 & 2.330 \\
\hline $\mathrm{OH}$ & 2.172 & 2.159
\end{tabular}


Table 3. Calculated Electrophilicity Values for Some Selected Molecules (eV). (continue)

\begin{tabular}{|c|c|c|}
\hline $\mathrm{F}_{2}$ & 3.864 & 3.860 \\
\hline $\mathrm{S}_{2}$ & 2.336 & 2.330 \\
\hline $\mathrm{CS}_{2}$ & 2.195 & 2.199 \\
\hline $\mathrm{CH}_{2} \mathrm{~F}$ & 2.383 & 2.345 \\
\hline $\mathrm{SO}_{2}$ & 2.278 & 2.330 \\
\hline $\mathrm{CHClBr}$ & 2.658 & 2.644 \\
\hline $\mathrm{O}_{3}$ & 2.337 & 2.330 \\
\hline $\mathrm{N}_{2} \mathrm{O}$ & 2.004 & 1.991 \\
\hline $\mathrm{PBr}_{3}$ & 2.891 & 2.820 \\
\hline $\mathrm{PCl}_{3}$ & 3.103 & 2.987 \\
\hline $\mathrm{CClBrl}$ & 2.958 & 2.946 \\
\hline $\mathrm{CH}_{3} \mathrm{I}$ & 2.126 & 2.171 \\
\hline $\mathrm{HNO}_{3}$ & 2.163 & 2.156 \\
\hline $\mathrm{SF}_{6}$ & 3.529 & 3.591 \\
\hline $\mathrm{CF}_{3} \mathrm{Br}$ & 3.236 & 3.286 \\
\hline $\mathrm{H}_{2} \mathrm{O}$ & 2.111 & 2.104 \\
\hline $\mathrm{CH}_{3} \mathrm{CHO}$ & 2.019 & 2.032 \\
\hline $\mathrm{NH}_{3}$ & 1.958 & 1.958 \\
\hline $\mathrm{CO}_{2}$ & 2.197 & 2.199 \\
\hline $\mathrm{CH}_{3} \mathrm{CN}$ & 1.945 & 1.959 \\
\hline $\mathrm{C}_{2} \mathrm{H}_{2}$ & 1.961 & 1.979 \\
\hline $\mathrm{CH}_{3} \mathrm{Cl}$ & 2.265 & 2.249 \\
\hline$\left(\mathrm{CH}_{3}\right)_{2} \mathrm{O}$ & 2.014 & 2.025 \\
\hline $\mathrm{HCN}$ & 1.902 & 1.932 \\
\hline$\left(\mathrm{CH}_{3}\right)_{3} \mathrm{P}$ & 1.943 & 1.957 \\
\hline $\mathrm{C}\left(\mathrm{CH}_{3}\right)_{4}$ & 1.970 & 1.988 \\
\hline$\left(\mathrm{CH}_{3}\right)_{2} \mathrm{~S}$ & 1.993 & 2.025 \\
\hline
\end{tabular}

invoked in the present work we have used the experimental I and A data of the corresponding molecules and hence the parameters are labeled as Experimental. The second sets of data (chemical hardness, electronegativity and electrophilicity) are computed using the corresponding geometric mean equation proposed by Datta, Sanderson and Chattaraj respectively. We labeled the result as geometric mean. The third sets of data are computed using the equations proposed by us. We labeled the data as Kaya.
It is seen from the results presented in Table 4 that the three sets of data shows good agreement. We have also noted that for small molecules the set 2 (geometric mean) and set 3 (Kaya) are numerically close to their experimental counterparts. On the other hand, in big molecules, the differences between calculated results via various theoretical methods and experimental data are obtained. From this observation we may conclude that the charge equalization process for very big molecules cannot be depicted by 


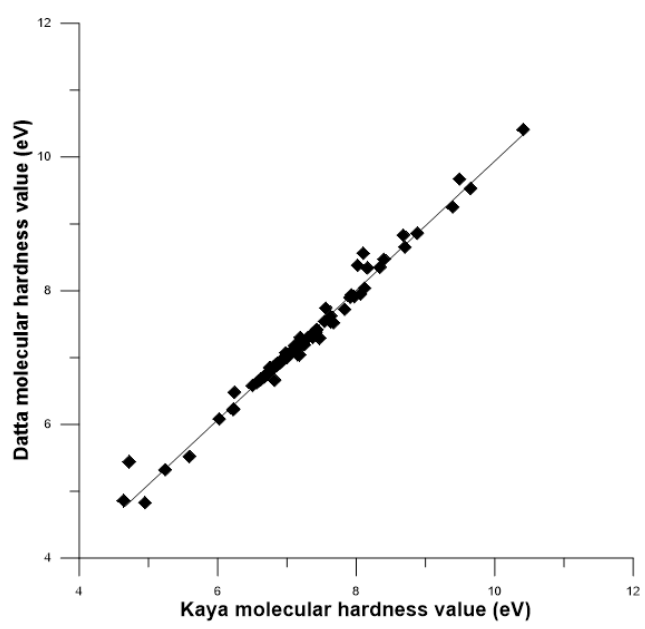

Figure 1. Comparison of the results obtained from Equation 2 and Equation 5 for molecules in Table 1.

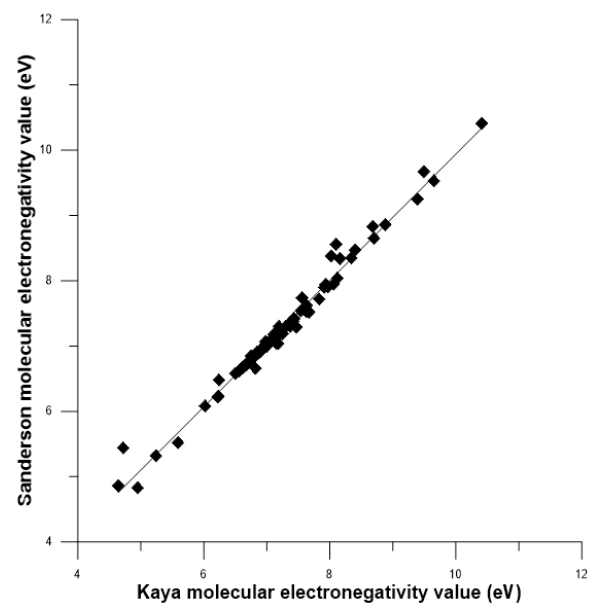

Figure 2. Comparison of the results obtained from Equation 1 and Equation 4 for molecules in Table 2.

Table 4. Chemical hardness, electronegativity and electrophilicity values calculated using various methods for some selected molecules.

\begin{tabular}{cccccccccc}
\hline \multirow{2}{*}{ Molecule } & \multicolumn{3}{c}{ Experimental (eV) } & \multicolumn{2}{c}{ Geometric Mean (eV) } & \multicolumn{3}{c}{ Kaya (eV) } \\
\cline { 2 - 10 } & $\chi$ & $\eta$ & $\omega$ & $\chi$ & $\eta$ & $\omega$ & $\chi$ & $\eta$ & 11.32 \\
\hline $\mathrm{CH}$ & 5.940 & 9.40 & 1.877 & 6.703 & 11.325 & 1.984 & 6.66 & 1.959 \\
\hline $\mathrm{OH}$ & 7.505 & 11.350 & 2.481 & 7.354 & 12.492 & 2.165 & 7.37 & 12.50 & 2.173 \\
\hline $\mathrm{NH}$ & 6.740 & 12.720 & 1.786 & 7.222 & 13.664 & 1.909 & 7.24 & 13.64 & 1.918 \\
\hline $\mathrm{F}_{2}$ & 9.390 & 12.620 & 3.493 & 10.410 & 14.021 & 3.864 & 10.410 & 14.02 & 3.864 \\
\hline $\mathrm{S}_{2}$ & 5.530 & 7.740 & 1.976 & 6.217 & 8.280 & 2.334 & 6.217 & 8.280 & 2.334 \\
\hline $\mathrm{CS}_{2}$ & 5.540 & 9.080 & 1.690 & 6.232 & 8.814 & 2.203 & 6.23 & 8.84 & 2.195 \\
\hline $\mathrm{SO}_{2}$ & 6.695 & 11.290 & 1.985 & 7.069 & 10.693 & 2.337 & 6.98 & 10.69 & 2.278 \\
\hline $\mathrm{NH}_{2}$ & 6.790 & 12.02 & 1.918 & 7.206 & 13.384 & 1.940 & 7.22 & 13.38 & 1.947 \\
\hline $\mathrm{N}_{2} \mathrm{O}$ & 7.180 & 11.420 & 2.257 & 7.358 & 13.696 & 1.977 & 7.41 & 13.70 & 2.003 \\
\hline $\mathrm{SO}_{3}$ & 6.350 & 9.300 & 2.168 & 7.184 & 11.041 & 2.337 & 7.11 & 11.04 & 2.289 \\
\hline
\end{tabular}


Table 4. Chemical hardness, electronegativity and electrophilicity values calculated using various methods for some selected molecules. (continue)

\begin{tabular}{|c|c|c|c|c|c|c|c|c|c|}
\hline LiF & 6.123 & 11.265 & 1.660 & 6.204 & 9.524 & 2.014 & 4.89 & 6.85 & 1.745 \\
\hline $\mathrm{LiCl}$ & 5.415 & 9.469 & 1.551 & 5.415 & 7.619 & 1.905 & 4.82 & 5.99 & 1.939 \\
\hline $\mathrm{LiBr}$ & 5.143 & 8.816 & 1.497 & 5.170 & 7.184 & 1.878 & 4.65 & 5.85 & 1.848 \\
\hline $\mathrm{NaF}$ & 5.524 & 9.687 & 1.578 & 6.123 & 9.306 & 2.014 & 4.72 & 6.62 & 1.682 \\
\hline $\mathrm{NaCl}$ & 5.116 & 8.490 & 1.551 & 5.333 & 7.456 & 1.905 & 4.64 & 5.81 & 1.852 \\
\hline $\mathrm{NaBr}$ & 4.898 & 8.00 & 1.497 & 5.116 & 7.020 & 1.850 & 4.51 & 5.63 & 1.806 \\
\hline KF & 5.197 & 9.497 & 1.415 & 5.578 & 8.435 & 1.850 & 4.13 & 5.76 & 1.480 \\
\hline $\mathrm{KCl}$ & 4.762 & 8.163 & 1.388 & 4.871 & 6.748 & 1.769 & 4.12 & 5.08 & 1.670 \\
\hline $\mathrm{KBr}$ & 4.571 & 7.674 & 1.361 & 4.680 & 6.367 & 1.714 & 4.03 & 4.95 & 1.640 \\
\hline $\mathrm{BeO}$ & 6.231 & 7.973 & 2.422 & 6.612 & 10.09 & 2.150 & 5.97 & 10.25 & 1.738 \\
\hline $\mathrm{MgO}$ & 4.898 & 5.905 & 2.041 & 6.068 & 9.333 & 1.986 & 5.36 & 8.88 & 1.617 \\
\hline $\mathrm{CaO}$ & 3.973 & 6.123 & 1.279 & 5.497 & 8.191 & 1.850 & 4.56 & 7.84 & 1.326 \\
\hline $\mathrm{BeS}$ & 5.823 & 6.939 & 2.449 & 5.769 & 8.218 & 2.014 & 5.54 & 8.70 & 1.764 \\
\hline MgS & 4.980 & 5.714 & 2.177 & 5.306 & 7.592 & 1.850 & 5.07 & 7.57 & 1.698 \\
\hline $\mathrm{CaS}$ & 4.191 & 5.606 & 1.578 & 4.816 & 6.667 & 1.742 & 4.440 & 6.81 & 1.421 \\
\hline DMF & 3.40 & 11.60 & 0.498 & 6.974 & 12.127 & 2.005 & 6.942 & 12.128 & 1.986 \\
\hline Toluene & 3.90 & 10.00 & 0.760 & 6.733 & 11.426 & 1.983 & 6.692 & 10.984 & 2.038 \\
\hline Propylene & 3.90 & 11.80 & 0.644 & 6.857 & 11.813 & 1.990 & 6.820 & 11.807 & 1.969 \\
\hline p-xylene & 3.70 & 9.60 & 0.713 & 6.753 & 11.489 & 1.984 & 6.712 & 11.482 & 1.962 \\
\hline Cyclohexene & 3.40 & 11.00 & 0.525 & 6.818 & 11.691 & 1.988 & 6.781 & 11.684 & 1.967 \\
\hline $\mathrm{C}_{6} \mathrm{H}_{5} \mathrm{OH}$ & 3.80 & 9.60 & 0.752 & 6.763 & 11.393 & 2.007 & 6.730 & 11.380 & 1.990 \\
\hline $\mathrm{C}_{6} \mathrm{H}_{5} \mathrm{SH}$ & 3.80 & 9.20 & 0.784 & 6.670 & 11.070 & 2.009 & 6.620 & 11.080 & 1.978 \\
\hline $\mathrm{C}_{6} \mathrm{H}_{5} \mathrm{NO}_{2}$ & 5.50 & 8.80 & 1.718 & 6.824 & 11.543 & 2.017 & 6.782 & 11.538 & 1.993 \\
\hline$\left(\mathrm{CH}_{3}\right) 3 \mathrm{~N}$ & 1.50 & 12.60 & 0.096 & 6.960 & 12.264 & 1.975 & 6.930 & 12.232 & 1.963 \\
\hline $\mathrm{CH}_{3} \mathrm{COCH}_{3}$ & 4.10 & 11.20 & 0.750 & 6.920 & 11.860 & 2.018 & 6.90 & 11.86 & 2.007 \\
\hline$\left(\mathrm{CH}_{3}\right) 3 \mathrm{P}$ & 2.80 & 11.80 & 0.332 & 6.830 & 11.880 & 1.963 & 6.790 & 11.860 & 1.943 \\
\hline$\left(\mathrm{CH}_{3}\right) 3 \mathrm{As}$ & 3.00 & 11.40 & 0.395 & 6.793 & 11.790 & 1.957 & 6.743 & 11.758 & 1.933 \\
\hline $\mathrm{C}\left(\mathrm{CH}_{3}\right) 4$ & 2.20 & 16.60 & 0.146 & 6.900 & 11.940 & 1.993 & 6.860 & 11.940 & 1.987 \\
\hline
\end{tabular}

the existing geometrical mean principles. Thus it is obvious that the existing geometrical mean model is not the perfect tool for the prediction of charge rearrangement during the large molecule formation. We may point out that there is a scope of some modified method for the depiction of the charge rearrangement during the formation of large molecule. We are working on the model and hope that in future we will present some sophisticated charge equalization model for the large molecules.

The expressed good agreement between the results obtained from our equation and the results obtained from geometric mean equation vide supra, leads us to conclude that Chattaraj's 


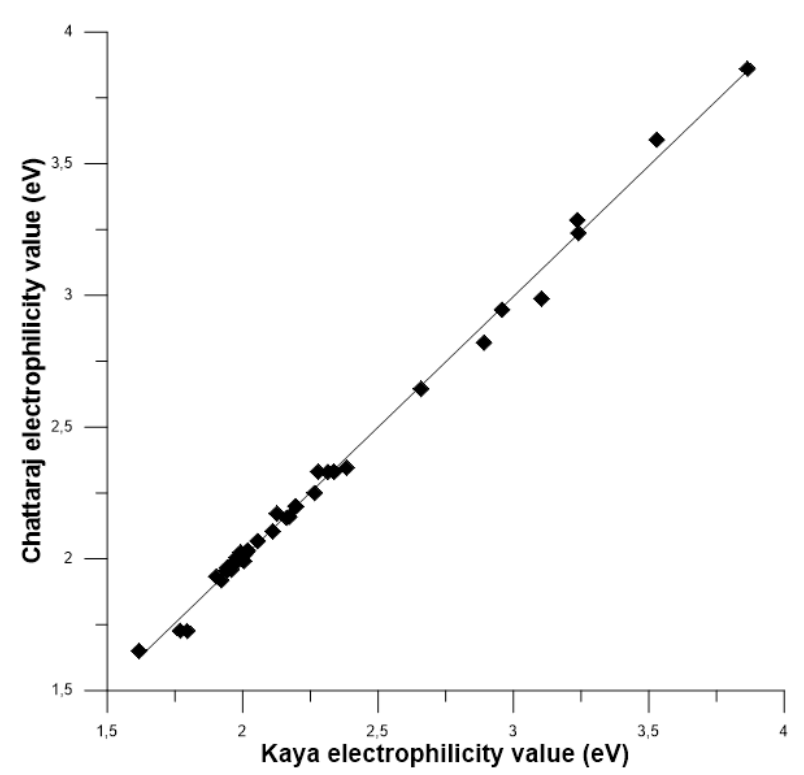

Figure 3. Comparison of the results obtained from Equation 3 and Equation 6 for molecules in Table 3.

geometric mean equation and other equalization principles are still useful and cannot be ignored completely.

\section{CONCLUSIONS}

In the present report, a support for the charge equalization principles is presented. We found that the charge equalization process for small molecule is successfully depicted by the geometrical mean models but for very big molecules the existing geometrical mean models failed to depict the charge equalization scenario. Considering the results presented in this study we can conclude that Chattaraj's electrophilicity equalization Principle and other equalization principles are useful and remarkable despite all the criticisizm about them.

\section{References}

1. R.G. Parr, W. Yang, Density Functional Theory of Atoms and Molecules; Oxford University Press: Oxford, U.K. 1989.

2. R.M. Dreizler, E.K.U. Gross, Density Functional Theory; Springer-Verlag: Berlin, 1990.

3. P. K. Chattaraj, Chemical Reactivity Theory: A Density Functional View; Taylor \& Francis/CRC Press: Boca Raton, 2009.

4. R.G. Parr, R.G. Pearson, Absolute hardness: companion parameter to absolute electronegativity, J. Am. Chem. Soc., 105 (1983) 7512-7516.
5. R.G. Pearson, Absolute electronegativity and hardness: application to inorganic chemistry, Inorg. Chem., 27 (1988) 734-740.

6. R.G. Pearson, Absolute electronegativity and hardness correlated with molecular orbital theory, Proc. Natl. Acad. Sci. USA., 83 (1986) 8440-8441.

7. R.G Pearson, Chemical hardness and bond dissociation energies, J. Am. Chem., Soc., 110 (1988) 7684-7690.

8. W. Kohn, A.D. Becke, R.G. Parr, Density functional theory of electronic structure, J. Phys. Chem., 100 (1996) 12974-12980.,

9. R.G. Parr, R.A. Donnelly, M. Levy, W.E. Palke, Electronegativity: the density functional viewpoint, J. Chem. Phys., 68 (1978) 3801-3807.

10. H. Chermette, Chemical reactivity indexes in density functional theory, J. Comp. Chem., 20 (1999) 129-154.

11. R.T. Sanderson, Chemical Bond and Bond Energy, Academic Press, New York, 1976.

12. R.T Sanderson, Electronegativities in inorganic chemistry:(II), J. Chem. Edu., 31(1954) 2.

13. R.G. Pearson, Chemical Hardness: Applications from Molecules to Solids, Wiley-VCH: Weinheim, Germany, 1997.

14. D.C. Ghosh, N. Islam, A quest for the algorithm for evaluating the molecular hardness, Int. J. Quant. Chem., 111 (2011) 1931-1941.

15. N. Islam, D.C. Ghosh, Hardness Equalization in the formation poly atomic carbon compounds, Chapter 13 Carbon Bonding and Structures: Advances in Physics and Chemistry, Springer, Editor: Dr. Mihai V. Putz, Carbon Materials: Chemistry and Physics, Volume 5, 301-319.

16. R.G. Pearson, Recent advances in the concept of hard and soft acids and bases, J. Chem. Edu. 64 (1987) 561.

17. R.G. Pearson, Hard and soft acids and bases, J. Am. Chem. Soc., 85 (1963) 3533-3539. 
18. P.K. Chattaraj, H. Lee, R.G. Parr, HSAB Principle, J. Am. Chem. Soc., 113 (1991) 1855-1856.

19. T.L. Ho, Hard soft acids bases (HSAB) principle and organic chemistry, Chemical Reviews, 75 (1975) 1-20.

20. R.G. Parr, P.K. Chattaraj, Principle of Maximum Hardness, J. Am. Chem. Soc., 113 (1991) 1854-1855.

21. R.G. Pearson, The Principle of Maximum Hardness Acc. Chem. Res., 26 (1993) 250-255.

22. R.G. Pearson, W.E. Palke, Support for a principle of maximum hardness, J. Phys. Chem., 96 (1992) 32833285.

23. D. Datta, Geometric mean principle for hardness eualization: a corollary of Sanderson's geometric mean principle of electronegativity equalization, J. Phys. Chem., 90 (1986) 4216-4217.

24. P.K. Chattaraj, S. Giri, S. Duley, Electrophilicity equalization principle, J. Phys. Chem. Lett., 1 (2010) 1064-1067.

25. R.G. Parr, L.V. Szentpaly, S. Liu, Electrophilicity index, J. Am. Chem. Soc., 121 (1999) 1922-1924.

26. L. von Szentpály, Ruling out any electrophilicity equalization principle, J. Phys. Chem., A, 115 (2011) 8528-8531.

27. P.K. Chattaraj, S. Giri, S. Duley, Comment on "Ruling out any electrophilicity equalization principle, J. Phys. Chem. A, 116 (2011) 790-791.

28. L.V. Szentpály, Reply to "Comment on'Ruling Out Any Electrophilicity Equalization Principle, J. Phys. Chem. A, 116 (2011) 792-795.

29. T.K. Ghanty and S.K. Ghosh, A density functional approach to hardness, polarizability, and valency of molecules in chemical reactions, J. Phys. Chem., 100 (1996) 12295-12298.

30. D. Datta, N.K. Shee, L.V. Szentpály, Chemical potential of molecules contrasted to averaged atomic electronegativities: alarming differences and their theoretical rationalization, J. Phys. Chem., 117 (2012) 200-206.

31. R.G. Pearson, Electronegativity Scales, Acc. Chem. Res., 23 (1990) 1-2.

32. L.C. Allen, Electronegativity Scales, Acc. Chem. Res. 23 (1990) 175-176.

33. P. Politzer, M.E. Grice, J.S. Murray, Electronegativities, electrostatic potentials and covalent radii, J. Mol. Struc. (Theochem), 549 (2001) 69-76.
34. P. Politzer, Z. Peralta- Inga Shields, F.A. Bulat, J.S. Murray, Average local ionization energies as a route to intrinsic atomic electronegativities, J. Chem. Theory Comput., 7 (2011) 377-384.

35. P. Politzer, J.S. Murray, M.E. Grice, Electronegativity and average local ionization energy, Collect. Czech. Chem. Commun., 70 (2005) 550-558.

36. R.P. Iczkowski, J.L. Margrave, Electronegativity, J. Am. Chem. Soc., 83 (1961) 3547-3551.

37. S. Kaya, C. Kaya, New equation based on ionization energies and electron affinities of atoms for calculating of group electronegativity, Computational and Theoretical Chemistry., 1054 (2015) 42-46.

38. S. Kaya, C. Kaya, A new equation for calculation of chemical hardness of groups and molecules, Mol. Phys., 113 (2015) 1311-1319.

39. N. Islam, D.C. Ghosh, On the electrophilic character of molecules through its relation with electronegativity and chemical hardness, Int. J. Mol. Sci., 13 (2012) 2160-2175.

40. D.C. Ghosh, N. Islam, Whether there is a hardness equalization principle analogous to the electronegativity equalization principle-A quest, Int. J. Quant. Chem., 111 (2011) 1961-1969.

41. J.L. Gazquez and F. Mendez, The Hard and Soft Acids and Bases Principle: An Atoms in Molecules Viewpoint, J. Phys. Chem., 98 (1994) 4591-4593.

42. S. Kaya, C. Kaya, A new method for calculation of molecular hardness: a theoretical study, Comp. Theor. Chem., 1060 (2015) 66-70.

43. S. Kaya, C. Kaya, Derivation of ionization energy and electron affinity equations using chemical hardness and absolute electronegativity in isoelectronic series, J. Phys. Theor. Chem., 11 (2015) 155-163.

44. S. Kaya, C. Kaya, Investigation of relationship with electron configuration of chemical hardness, absolute electronegativity and electrophilicity, J. Phys. Theor. Chem., 11 (2014) 1-13.

45. S. Kaya, S.E. Kariper, A. Ungördü, C. Kaya, Effect of some electron donor and electron acceptor groups on stability of complexes according to the principle of HSAB, J. Result. Sci., 4 (2014) 82. 